\section{HIV/AIDS in Cuba: lessons and challenges}

\section{Tim Anderson ${ }^{1}$}

Suggested citation: Anderson T. HIV/AIDS in Cuba: lessons and challenges. Rev Panam Salud Publica. 2009;26(1):78-86.

Key words: HIV, acquired immunodeficiency syndrome, health promotion, Cuba.

\footnotetext{
1 Political Economy Department, University of Sydney, Australia. Send correspondence to: Dr. Tim Anderson, Political Economy, University of Sydney, N.S.W., 2006, Australia; telephone: 2-9351-4783; email: t.anderson@usyd.edu.au.
}

Cuba, a relatively poor, socialist, developing country has the lowest rate of HIV infection in the Caribbean subregion and a rate among the lowest in the world. Yet when we look at the published explanations for this, outside Cuba, we face a wall of controversy and disdain. A fair amount of the criticism seems due to ideological wars and the economic blockade by the United States of America (US) imposed on Cuba. The latter certainly undermines communication, scientific exchange, and understanding.

Cuba's achievements in public health and its relative success in containing the HIV/AIDS pandemic deserve restating, but they are relatively uncontroversial. This paper suggests that it is Cuban methods and the understandings of those methods that deserve greater attention. Particular ideas persist, outside Cuba, about the Cuban HIV program: that its success has been due to policies of isolation, coercive testing, and an anti-homosexual approach. Very little of this forms part of the perspective of contemporary Cuban health professionals, who typically say that their program has both drawn from and contributed to global themes of health promotion, participatory education, sexual inclusiveness, contact tracing, and targeted and voluntary testing. There is also a broader Cuban theme called "intersectoral cooperation" that stresses a coordinated social response to health challenges.

This paper takes a historical perspective on Cuba's achievements in HIV / AIDS control, seeking to identify key elements of its relative success. The analysis covers international literature, Cuban medical reports, epidemiological data, and current health promotion materials and manuals, as well as interviews with Cuban health professionals and HIV-positive patients.

\section{ACHIEVEMENTS}

The United Nations Program on HIV/AIDS (UNAIDS) notes that, "by far the smallest epidemic in the Region [of the Americas] is in Cuba," evidenced by its sexually-active adult infection rate of $0.1 \%$ (1). Table 1 shows infection rates and antiretroviral drug coverage rates for Cuba and many of its closest neighbors.

Cuba's relative success in containing the pandemic is the most remarkable because the Caribbean subregion has the second highest rate of HIV infection in the world (1); plus, sexually-permissive Cuba appears particularly exposed to risk, since it receives about 2 million tourists per year. While there have been gradual increases in newly-reported HIV infections since the late 1990s, mostly among homosexual and bisexual men, Cuba's epidemic remains the smallest in the Caribbean subregion (2). Globally, of the 168 
TABLE 1. HIV infection rates and antiretroviral therapy (ARVT) coverage, Caribbean and North America, 2006

\begin{tabular}{|c|c|c|c|c|c|c|c|c|c|}
\hline & Haiti & Honduras & Jamaica & $\begin{array}{c}\text { Dominican } \\
\text { Republic }\end{array}$ & $\begin{array}{c}\text { United } \\
\text { States } \\
\text { of America }\end{array}$ & Colombia & $\begin{array}{l}\text { Costa } \\
\text { Rica }\end{array}$ & Mexico & Cuba \\
\hline IR: $2006^{a}$ & 3.8 & 1.5 & 1.5 & 1.1 & 0.6 & 0.6 & 0.3 & 0.3 & 0.1 \\
\hline ARVT: $2006^{b}$ & 20.0 & 35.0 & 56.0 & 36.7 & 70.1 & 44.0 & 80.0 & 71.0 & 100.0 \\
\hline
\end{tabular}

alR $=\%$ adults $15-49$ years of age infected with $\mathrm{HIV}(1)$

${ }^{\mathrm{b} A R V T}=\%$ antiretroviral drug coverage (1).

countries ranked by UNAIDS, Cuba ranks as one of 51 countries with an infection rates less than $0.2 \%$ (3). Detection rates seem high. One Cuban study estimated that the country was detecting 75\%-87\% of HIV infections, and attributed this relative efficiency to the country's thorough contact tracking system (4).

In fact, by late 2008, Cuba's infections had risen further, approaching $0.15 \%$ of sexually active adults (Table 2). While still a significantly lower rate than its neighbors', this increase represents an ongoing challenge; that said, treatment regiments have advanced. In the 1990s, full antiretroviral treatment (ARVT) was not available or affordable, and Cuba relied on foreign donations and government purchases for mothers and babies-a continued priority in Cuba's health policy. In 2001, however, universal and free antiretroviral treatment was introduced and AIDS deaths fell markedly. There had been 141 deaths in 2000; in 2003 there were just 70 (5). Table 2 shows Cuba's national HIV data for late 2005, 2007, and 2008 (6-8).

\section{MISPERCEPTIONS}

Discussion of virtually any topic concerning Cuba tends to be overshadowed by ideological positions, and more concretely conditioned by the economic blockade imposed on Cuba by the United States since the 1960s. Despite overwhelming rejection of the blockade every year by the United Nations (UN) (9), it continues to play a role in the HIV debate. For example, the United States Government did not grant a visa to Cuba's Minister of Health who had planned to address the 2006 UN Conference on HIV/AIDs in New York (10). Scientific and cultural exchanges are routinely blocked, and unless the United States Treasury has issued a special permit, US researchers are prohibited from studying any health issues in Cuba (11). In the context of ongoing "trading with the enemy" laws, it is not surprising that many in the US are unaware of Cuba's achievements or have a negative perception of the country's health programs.

The first point of criticism was that Cuba imposed a mandatory quarantine of its first HIV-infected individuals at health resorts or sanatoria (1986-1989). A 1988 Los Angeles Times report of a US delegation that visited a sanatorium described it as "pleasant, but frightening" and wrongly claimed that Cuba had "mandated universal HIV testing" (12). The following year a US medical report noted wide-scale and targeted testing, but claimed "Cuba has not made education the key focus of its anti-AIDS strategy" (13). After removal of the quarantine in 1989, criticism of Cuba's sanatoria continued, though at times educational programs were noted. One medical report suggested "the quarantine policy may paradoxically permit most Cubans to feel that they are personally invulnerable to the HIV epidemic" (14). The US media maintained a line of "freedom denied." Bauza and Collie described an HIVinfected gay man in a pleasant environment at Los Cocos health resort, but claimed "in return for all this, [the man] gives up his freedom" (15).

Individual cases, and the testing regiment, were used to reinforce this "loss of freedom" theme and to explain Cuba's relative success. One medical report, noting that Cuba had an HIV-infection rate "nearly 11 times lower than the United States," suggested that this could be due to being "politically and socially isolated," to Cubans being less susceptible to risk factors-such as poverty and social inequality-and to "aggressive HIV screening and subsequent contact

TABLE 2. HIV/AIDS cases in Cuba, 1986 to 2008

\begin{tabular}{lllr}
\hline National data from 1986 to: & \multicolumn{1}{c}{$2005^{\mathrm{a}}$} & $2007^{\mathrm{b}}$ & $2008^{\mathrm{c}}$ \\
\hline Total HIV seropositive & 6827 & 8873 & 10454 \\
Total AIDS cases & 2782 & 3387 & 3910 \\
Total AIDS deaths & 1405 & 1534 & 1721 \\
Seropositive males & $5468(80.1 \%)$ & $7159(80.7 \%)$ & $8363(80.0 \%)$ \\
$\quad$ HSH (homo-/bisexual male) & $4707(68.9 \%)$ & $6025(67.9 \%)$ & $7119(68.1 \%)$ \\
Seropositive females & $1339(19.6 \%)$ & $1714(19.3 \%)$ & $2090(20.0 \%)$ \\
\hline a 22 November 2005 (6). & & & \\
b28 August 2007 (7). & & & \\
c18 November 2008 (8). & & &
\end{tabular}


tracing of infected individuals" (16); however, at the time of this report there had been nearly a decade of mass tourism, so "isolation," at least, was improbable.

Hostile and mistaken attitudes persist in much of the academic and popular foreign literature. For example, despite some initial useful details regarding the AIDS program in Cuba, $d^{\prime}$ Adesky devotes much of her article to two patients unhappy with its "paternalistic nature," focusing on the pressure to attend classes and reveal sexual contacts (17). This report misstates the profile of the Cuban HIV-positive population, suggesting it was "almost entirely in gay and bisexual men" - when in fact, it is a little under 70\% — and concludes by suggesting that Cuba was hoping for foreign donations of highly active antiretroviral (HAART) medications (17). Such donations were indeed relied upon in the 1990s; however, by the time of d'Adesky's report, Cuba had $100 \%$ free ARVT coverage (5). Similarly Brotherton, relying mainly on US sources and with little detail on Cuba's actual program, stresses the topic of "social control" and discounts more favorable, evidence-based analysis as "statistical fetishism" (18). Whiteford and Branch, in their 2008 book, rely on some fairly outdated sources to erroneously suggest that quarantine may still be used in Cuba's program (19). Many of these commentaries share some common features: they make little use of Cuban sources; have little factual detail on Cuba's HIV / AIDS program; and tend to rely on anecdotal evidence to support broad characterizations of the Cuban system.

Some US authors have reported the Cuban response to HIV / AIDS more favorably. Byron Barksdale told the American Association for the Advancement of Science that the United States could learn lessons from Cuba, drawing attention to Cuba's 6-week "living with HIV" program: "that is certainly a longer time than is given to people in the US who receive such a diagnosis. They may get about five-minutes-worth of education" (20).

Others have changed their positions on Cuba's handling of the HIV epidemic. A Canadian academic observed: "in the mid-1980s Cuba was widely condemned . . . by the late '80s, however, Cubans were more knowledgeable about the epidemic" (21). Peter Piot, executive director of UNAIDS, had been a critic of Cuba's policy in the 1980s, but in 2003 said that "Cuba was one of the first countries to take AIDS seriously as a problem, and provide a comprehensive response combining both prevention and care" (20). UNAIDS now commends the broader elements of Cuba's strategy: "Cuba has mobilized an effective multisectoral response to HIV / AIDS since the 1980s . . p partnerships with public and civil society organizations have been strengthened" (22).

\section{PROGRAM DEVELOPMENT}

The range of foreign misperceptions and misrepresentations call for more careful reviews of the major elements of Cuba's program and how they developed over time. Such reviews should address the concrete evidence and focus more attention on the views of Cuban professionals and patients, and less on foreign stereotypes.

A practical approach to understanding Cuba's program is divide it into the following distinct elements: (a) testing and tracing; (b) quarantine, sanatoria, and daycare; (c) treatment; (d) health promotion and education; and, (e) intersectoral work.

\section{Testing and tracing}

Testing began in 1986 and was expanded the following year to include vulnerable groups, i.e., pregnant women, health workers, blood donors, and those who had traveled to areas with a high incidence of the disease (5). The sexual contacts of HIV-positive individuals were traced. By February 1988, around 25\% of the sexually-active Cuban population had been tested. There were positive results among nearly $4 \%$ of the contacts who had been traced and tested, a far higher level than among other groups targeted for testing (23). This high rate of discovery would seem to justify some insistence on the part of health professionals, over the pursuit of sexual contacts. The vulnerable groups mentioned remain the principal targets of Cuban testing. By 2003, approximately 1.6 million tests were conducted (5).

November 2005 data for the "Plaza" municipality, which has a high rate of infection by Cuban standards, provides an example of an HIV-positive population and how its infections were detected. Over the past 20 years, this municipality has had 280 infected people, 57 of whom have died and 223 classified as "living with HIV." Of the 223 living with HIV, 187 were day care patients, 25 were in a sanatorium, 19 went overseas, and several were in a specialized hospital or in private care (24). For the 280 with HIV, the predominant method of discovery was by: routine family-physician consultations, 74 individuals; tracing of sexual contacts of infected persons, 55; hospital inpatient testing, 43; STD testing, 36; self-reports, 31; blood donor tests, 29; and prisoner tests, 9. A little over $15 \%$ were female and $75 \%$, homosexual or bisexual men (24).

HIV cases in Cuba, as with some other diseases (leprosy, for instance) are confidentially registered with the National Center for Epidemiology. This information is protected by law, with penalties for breaches in the privacy of patient records. ${ }^{2}$ Testing is mostly done through the family doctor, or anonymously, through a polyclinic. Clinics can request testing, but individuals can refuse. In the case of a positive HIV finding, a structured interview is conducted that requests contact information for all of the individual's sexual partners in recent years. These contacts are followed-up privately by the family doctor, often assisted by a nurse. While the contact tracing process is

\footnotetext{
2 Interview with Anian Canal Segredo, Instituto Pedro Kourí, Havana 3 January 2006; a specialist nurse in HIV treatment centers, previously at Los Cocos Sanatoria.
} 
thorough, a senior epidemiologist explained that blood tests always require patient consent, a fundamental element of medical practice in Cuba. ${ }^{3}$ Some people do complain about testing requests and tracing of sexual contacts $(13,17)$.

Complaints about invasions of privacy in testing and contact tracings are hardly unique to Cuba. Pressures for wider HIV testing are common as well. For example, the United States Centers for Disease Control and Prevention (CDC) guidelines propose universal testing, not just of target groups, but of all sexuallyactive individuals. When tests are refused, follow-up methods to reinvite testing should be employed (25).

What may be unique to Cuba is that the persuasive methods spring from the wider moral pressures and demands for social responsibility that permeate Cuban society. An emphasis on the infected person's social responsibility take precedence over the individual right to "opt out" or abstain from epidemiological tracing. An emphasis on "trustworthiness" (confiabilidad) of the HIV educational programs $(26,27)$ underscores this point. Apart from this cultural difference, which may add thoroughness to testing, the formal processes of targeting, voluntariness, and privacy protection in the current Cuban testing system appear unremarkable.

\section{Quarantine, sanatoria, and day care}

Three misperceptions persist regarding the quarantine period that took place in Cuba. First, it is sometimes suggested that the practice continued into the 1990s. Second, it has been suggested that the quarantine period was aimed at homosexual men (e.g., 28). Third, current use of health sanatoria in Cuba is sometimes wrongly equated with quarantine (e.g., 19).

Cuban responses to criticism of the 1986-1989 quarantine period have included that it was an emergency response, when little was known about the disease, and the practice has since changed ${ }^{4}$; and that the initial period gave health care workers a useful "space" to prepare a more knowledgeable response (29). A National AIDS Commission was established in 1983, with President Fidel Castro charging the Instituto Pedro Kourí (IPK) to ensure that this epidemic "does not constitute a health problem for Cuba" (30). The first Cuban AIDS case was not diagnosed until 1985, but the decision to proceed with quarantine was based on a 1982 law that allows for isolating those carrying an infectious disease that presents a public threat (30).

The first sanatorium in the province of Havana was joined by several others elsewhere on the island. Conditions in the sanatoria were certainly not harsh, and a smaller group of patients remain in sanatoria voluntarily, to this day, because of the favorable environment, food, and institutional support, or because of

\footnotetext{
3 Interview with Teresa Vilacha, Vice-Director of Epidemiology at La Rampa Polyclinic, Havana, 21 December 2005.

4 Interview with Angel Yera, Coordinator of the People Living with HIV/AIDS Program in the Plaza municipality, Vedado, Havana, 22 December 2005.
}

issues at home. More recently Cuba has used quarantine with dengue fever victims (29). Nevertheless, the stigma and fear of HIV/AIDS, especially in the early years of the epidemic, has been acknowledged (30), and it seems may have led to an unreasonable extension of the quarantine period through 1989.

Quarantine, however, was not aimed at homosexual men, who remained a minority of those infected in the 1980s. The initial group affected was mainly heterosexual men, returning from aid missions in Africa. While there was fear and stigma towards the disease in the first years, there were no particular social prejudices against this group. In general, expressions of social rejection were said to be "very isolated" (5). By 1988, Cuba had 190 HIV-positive cases, and seven deaths. Homosexual and bisexual men were by this time over-represented, but still formed a minority (39 cases $/ 21 \%$ ) of cases; at that time, an equal number of men and women were infected (23). Homosexual men were thus a minority of those quarantined, so the stigma of HIV infection (fear of the new disease) and of homosexuality (in a macho culture with significant homophobia) did not coincide. Nevertheless, the Cuban pattern of infection shifted from the African (mainly heterosexual) to the Western (mainly homosexual) pattern in the 1990s.

From 1989 onwards, patients could come and go from the sanatoria. In 1993, the day care program (sistema de atención ambulatoria, SAA) was introduced, allowing "patients to choose between living in a sanatorium or living at home" (32). Newly infected patients were required to attend a course that is now called "Living with HIV." Those in the day care program live at home but attend clinics daily. They receive the same treatment as those at the sanatoria, including special food supplements, such as milk, fiber, and vegetables. ${ }^{5}$ After the first few months of close observation, patients are monitored as outpatients by their family doctors (5). In January 1998, the "Hospital for a Day" was opened to provide morning sessions in the sanatoria for the Living with HIV program (31). Some of these programs were then managed by support teams, so that by the 2000s many newly-diagnosed patients were not entering sanatoria at all. In this case, the Living with HIV program is handled by peer educators, often HIV-positive themselves, in a community-based "Line of Support" for those living with HIV / AIDS. ${ }^{5}$

Some US researchers have reported that patients were free to leave their sanatorium "if they were healthy, had completed the HIV training course, and were enrolled for social services" (17). Others have noted that the relatively high rates of voluntary residence in the sanatoria during the economicallydepressed 1990s appear due to the relatively good conditions and rich diet offered $(15,16,32)$. In addition, residents were free to come and go, and could receive daily visits from family and friends.

\footnotetext{
5 Interview with Angel Yera,
} 
By the mid-2000s, however, the numbers in the sanatoria appeared to be shrinking; for example, in 2005, the Plaza municipality had seven times more patients in day care, than in the sanatorium (24). Two health promoters confirmed that, in 2005 the majority of those diagnosed with HIV in that municipality did not enter the sanatorium at all. ${ }^{6}$ At the national level, in $2008,74 \%$ of HIV-positive persons were listed as in the day care program, with the rest either attending the Living with HIV program or voluntarily residing at the sanatorium (8).

Nevertheless, the expansion in day care seems to have left a concentration of the marginalized in the small sanatoria populations. In 2002-2003, of the 267 patients at the Los Cocos sanatorium, $80 \%$ had some family dysfunction, $66 \%$ had been unemployed, over $40 \%$ had some psychiatric disorder, and over $50 \%$ had only basic secondary schooling (a low level in Cuba). This has been cited in Cuba as evidence of the need to further develop integrated systems of social support and thereby prevent isolation of marginalized people (31).

In summary, the early quarantine practice followed a strong directive to protect public health. It seems that overreaction and fear of the disease, even among health professionals (30), led to an unreasonable prolonging of the quarantine; however, it was not a measure targeting homosexual men, who were only a minority of infected patients at the time. In the 1990s, day care programs complemented the sanatoria, practically replacing them by the mid-2000s. Sanatoria continue to serve as useful centers for respite and treatment, but they pose new challenges arising from the semi-permanent, marginalized minority.

\section{Treatment}

Newly-infected patients attending the Living with HIV courses address a series of issues, set out in the course booklet. Included in the course are: clinical information, HIV and the social environment, information on support groups, nutrition and hygiene, "responsible" sexuality, and some legal matters. The booklet explains drug therapy, the development of support groups, and self-help strategies, as well as the rights and responsibilities of HIV individuals in relation to work, social security, health, and confidentiality (26). A similar booklet and course, "Living Together with HIV," is designed for the families of patients (33). Peer educators who run the courses at the day care program get leave from their regular employment. Some of the peer educators also act as coordinators between the broader range of groups involved in the HIV / AIDS program. As their roles have taken on more responsibility, some have put pressure on the government to provide direct funding for these voluntary positions. ${ }^{7}$

Drug treatment for patients took some time to develop, in large part due to the economic hardships

\footnotetext{
6 Interviews with Angel Yera; and with Roberto Cruz, 4 January 2006, Havana, Provincial Coordinator of the Line of Support for HIV/ AIDS in Vedado, Havana.

7 Interview with Roberto Cruz.
}

of the 1990s and the US blockade. The use of immune system boosting drugs was recommended in Cuba from 1986 onwards. In 1987 zidovudine (ZDV) was recommended for all those who developed AIDS. With limited drugs, Cuban experts stressed the need for an "intense educational campaign" designed to lower the risk of infection, emphasizing reduced "sexual promiscuity" and promoting stable relationships (23). Later literature would retain reference to responsible sexuality, but caution against pejorative use of the term "promiscuous" (27). In 1996, after the Worlds AIDS conference and the recommendation of HAART, Cuba purchased ARVT drugs for all children with AIDS and their mothers, at a cost of US\$ 14000 per person per year. This strained the nation's resources, following its deep economic crisis. At the same time, in 1998-2001, NGOs donated enough ARVT drugs to treat 100 Cuban AIDS patients (5).

In the 1990s, not all Cubans with AIDS had received treatment; but from 1998 onwards, with the economy recovering and the gradually growing number of HIV cases, generics were developed. Cuba was well positioned for this, due to its biomedicine industry. The first drug produced was zidovudine (ZDV). Then in 2001, lamivudine (3TC), stavudine (D4T), zalcitabine (DDC), didanosine (DDI), and indinavir (IDV) were produced. Bioequivalence was assessed and those drugs were registered before use. Production of nevirapine (NVP), abacavir (ABC), efavirenz (EFV), and nelfinavir (NFV) was then assessed (5). The full "cocktail" was finally made available. After 2001, there was no further need for foreign assistance with HIV drugs (5), except for procurement of western blot test material. $^{8}$

Since 2001, $100 \%$ of Cuba's HIV-positive patients have had access to a relatively full cocktail of ARVT drugs, free of charge. As a result, deaths from AIDS have fallen and most HIV-positive Cubans are avoiding secondary infections. Treatment for those suffering the opportunist infections of AIDS has been coordinated through the Pedro Kourí Institute, which specializes in tropical medicine. ${ }^{9}$

With economic growth and readily available ARVT drugs, Cuba shifted to pre-emptive treatment. Some countries require an immune system measure below a certain level, plus an opportunistic infection, before ARVT is given. Cuba seems to have begun taking this approach, requiring a CD-4 cell count below 350, a viral load above 55000 copies per $\mathrm{mL}$, and some opportunistic infection before ARVT treatment is begun (5). However, a Cuban health promoter involved with treatment compliance reported that in late 2005, the practice had shifted to administering treatment when cell counts were low, without any apparent illness. ${ }^{10}$ This change, independent of drug cost pressures, might indeed produce better results. The nutritional supplements provided to Cuba's HIV positive patients are also designed to assist recovery.

\footnotetext{
8 Interview with Anian Canal Segredo.

9 Interview with Teresa Vilacha.

10 Interview with Angel Yera.
} 
The serious treatment problem of the 1990s seem to have been overcome. Cuba has taken substantial steps toward delivering on its constitutional promise (Article 50) to deliver "free medical and hospital attention" to HIV / AIDS sufferers.

\section{Health promotion and education}

Education has always been an important part of Cuba's approach to HIV/AIDS, but its approach has changed. In the late 1990s shifts in strategic principles were formalized, as outlined in Table 3 below. The main, practical differences were the emphasis on health promotion and peer education.

While Cuba has its own strong history in educational development, outside influences have been incorporated. The country took seriously the discussions of the First International Health Promotion Conference (Ottawa, Canada, 1986) and began to elevate the notion of "health as a source of the richness of life," regarding programs of prevention as "doors of entry" to health promotion (27). This principle, and a stronger emphasis on social support and participation, was established by the time of the 1998 revised policy issued by the newly formed Centro Nacional de Prevención de las ITS (National Center for the Prevention of STDs and HIV/AIDS, Havana, Cuba). Health promotion thus began to supersede prevention.

The need to periodically review education programs was noted. The manual for groups working in HIV/AIDS prevention refers to a method developed by US academic David Kolb, a teaching and learning process that emphasizes a circular relationship between concrete experience, observation, reflection, conceptualization, and practice (34). Long-term cooperation was developed with some international agencies, in particular, the World Health Organization and the United Nations Development Program. The National Center for the Prevention of STDs and HIV / AIDS, for example, was created in 1998, with support from the UNDP and Doctors without Borders (Geneva, Switzerland) to help expand HIV education (35).

Much of the Cuban health promotion material seen in 2005 was aimed at the general population, with some material aimed more directly at homosexual men or addressing the male responsibility for condom use. Another national pamphlet addressed cultural attitudes, urging readers to "judge your friends by their qualities, not by their sexual preferences" and stressing acceptance of "sexual diversity" to counter "preju-

TABLE 3. Cuban HIV/AIDS strategic principles, 1986 vs. 1998

\begin{tabular}{ll}
\hline 1986 & \multicolumn{1}{c}{1998} \\
\hline & $\cdot$ Information \\
- Epidemiological vigilance & - Capacity building \\
- Medical assistance & Education \\
- Epidemiological and clinical & - Counseling \\
research education & - Research \\
& - Communication \\
\hline
\end{tabular}

dices and stigmas." It noted that "homosexual, bisexual, or transvestite . . . are simply forms of sexual expression, as is heterosexuality," and that understanding and accepting people as they are, will make you grow into a better person." Local music stars have been enlisted to help promote safe sex, for example in the national HIV magazine.

The National Center for Sex Education (CENESEX, Havana, Cuba) has complemented this campaign, with its programs of sexual diversity and sexual inclusion (36), while the Director of the National Center for the Prevention of STDs and HIV has stressed the promotion of sexual diversity, so as to break down the cultural stigmas impeding preventive health campaigns. "Everything we can do to educate [people] about sexual diversity directly influences the HIV / AIDS epidemic," she said (37). The Government backed this campaign by hosting events for the International Day against Homophobia (17 May 2008) and the launching of the "Together with You" Campaign (14 June 2008) (38).

\section{Intersectoral work}

There is reason to believe that the intersectoral approach, namely through coordinating of agencies and program principles, has played a part in the strengthening of Cuba's HIV effort. Apart from the parallel work of the National Center for the Prevention of STDs and HIV/AIDS and CENESEX, most ministries and branches of government, including the police, courts, and prosecutors, as well as student groups, radio and television, sports institutes, and farmers groups were given roles in the 1996 "Intersectoral Plan" for the prevention of STDs and HIV / AIDS $(27,34)$. The result was school and television programs and advertisements against homophobia in shops and public buildings. Health promoters are screened for their ability to develop the personal skills needed for the role, that is: listening and communication skills, interpersonal relation-building, respect and tolerance, and consensus-building among groups (34).

By way of testing some provisional conclusions, I ran a straw poll that asked three Cuban health professionals, all with experience in the HIV program, the question: "Cuba now has a very low HIV infection rate. In your opinion, what are the reasons for this 'success' in controlling HIV/AIDS?" They were asked to choose from four possible explanations, and were given a space to comment. All three replied that, "The general commitment and strength of the Cuban health system," "the intersectoral work of this program," and "epidemiological vigilance" were "very important" or "important." None of them felt that, "The isolation of infected persons in sanatoria" was an important factor. ${ }^{11}$ The latter was hardly surprising, as quarantine isolation, at that stage, had not existed for over 16 years. Comments included: "the general level of edu-

11 Interviews with Teresa Vilacha; Anian Canal Segredo; and Marcia Iglesias Castaño (senior manager, social surveys and statistics at BISE, Havana, 7 January 2006). 
cation,"12 the "human factor," and social solidarity, ${ }^{13}$ and free health care, access to services, and education. ${ }^{14}$ When asked what she thought was the key to Cuban success, the nurse-specialist said: "It is the constant care given to the persons with HIV, and to their families; secondly, the united work of all the social and health organizations in this country, but above all it's the human effort."15 This was not a representative poll, but the feedback may add some personal insights on the system.

The officially-stated strategic principles of the Cuban program begin with a concerted and intersectoral approach to health problems, combined with strong epidemiological surveillance, extensive education campaigns, a free public health system, and social solidarity. Notions of social integration, rather than isolation, remain strong in the Cuban system. On the one hand, this is an element that is often characterized by outsider observers as a "social control" factor; but, on the other hand, it mitigates against the other foreign misperception of isolation. The commitment to social inclusion was reflected in comments made by a nurse-specialist, with nine years experience in Cuba's HIV/AIDS programs: "From the time a person is diagnosed, it is the responsibility of the State to put that person back in society to resume their normal life ... so that they don't feel rejected, so they know this is a person living with a virus, or an illness, but that this is nothing to be ashamed of."15

An important structural element of Cuban social inclusion has been that all HIV-positive patients, by law, maintain their job entitlements and $100 \%$ of their salary during absences due to the program or treatment (31). ${ }^{16}$ This cannot happen in countries that lack strong social security. Despite this law, some Cuban employers have tried to remove some HIV-positive people from their jobs. In a survey of 80 patients who had moved from the Los Cocos sanatorium to the day care program, 16 had faced attempts to remove them from their work. For the 12 who had permanent jobs, these attempts did not succeed, except in the case of one, who got discouraged and abandoned his appeal. However, four who had been on temporary contracts lost their jobs, even though they had been considered good workers. Some health workers have also faced pressures, for example, to move their place of work to a HIV patient care facility, such as a sanatorium. This has led to calls for greater clarity in antidiscrimination procedures, and more social support consistent with "the principles of solidarity of Cuban society" (31).

There is reason to believe that the intersectoral approach, namely through coordinating of agencies and program principles, has played a part in the strengthening of Cuba's HIV effort.

\footnotetext{
2 Interview with Marcia Iglesias Castaño.

13 Interview with Anian Canal Segredo.

14 Interview with Teresa Vilacha.

15 Interview with Anian Canal Segredo.

16 Interview with Angel Yera.
}

\section{LESSONS LEARNED}

What has been understood and misunderstood about the Cuban HIV / AIDS program? And what are the lessons from Cuba regarding HIV/AIDS? Some others have attempted to address these questions.

A group of Cuban and French researchers and health professionals surmised that the policy of extensive testing and contact tracing "may be an important factor," as well as education through the public media and schools. However, the rising infections were "worrying," especially among homosexual and bisexual men (39). A detailed report by Gorry stressed the integrated nature of all elements of the Cuban program, suggesting this was a clear "rights-based approach" in terms of privacy, health promotion, peer education, and participation, as well as guaranteed treatment and counseling (40). Gorry considers the major challenges for Cuba to be the impact of the US economic blockade on the health care system, underreporting of infections, the steadily rise in HIV infections among gay and bisexual men, and the persistent cultural stigma toward sexual diversity and the disease (40). With regard to underreporting, however, if the estimates of one Cuban study in 2003 (4) are accurate, this would seem to be less of a problem than elsewhere.

During the past decade, the main developments in Cuba's program have been the rise of the day care program, the Living with HIV courses, the increased role of peer educators, and, since 2001, an ARVT coverage rate of $100 \%$. No neighboring country has this level of treatment. The Cuban infection rate among sexually-active adults has risen gradually in recent years, from $0.1 \%$ to nearly $0.15 \%$. Nevertheless, this rate is still well below that of any of its neighbors. The reasons for Cuba's relative success, this paper suggests, are not well understood outside Cuba. During its two-decade experience with HIV/AIDS, Cuba's methods have been alternately ignored or misunderstood. Misunderstandings appear to be most prevalent in the US literature.

Outside views of the testing regime have been criticized through anecdotal material centering on complaints over privacy. Yet the formal practice of targeted testing, patient consent, and legal privacy protection are not so different in Cuba than in many developed countries. Nevertheless, the Cuban emphasis on social responsibility and its related moral pressures do create a distinct climate for testing and thorough contact tracing. It is likely that Cuban health professionals see such moral pressures as a plus, not a problem.

Isolation of patients has played little part in Cuba's program or its success. There has been no quarantine for the past 20 years, a period corresponding to most of the epidemic in Cuba. The 1986-1989 quarantine period was excessive, however it was not aimed at homosexual men, who at that time constituted about $20 \%$ of infected persons in the late 1980s. The sanatoria continue to play a lesser, but probably important, role in the HIV program of respite and treatment. 
However, extended voluntary residence in the sanatoria has led to a new challenge for social inclusion, a concentration of a minority group with high levels of psychological, social, and family support problems.

Cuba's approach to HIV education programs evolved over the 1980s and 1990s by incorporating some important outside influences. "Health promotion" began to supersede "prevention," particularly through peer educator-led activities. Since the 1990s, some international agencies have been directly engaged with HIV education in Cuba.

Finally, one uniquely Cuban feature of the overall HIV/AIDS program has been its strong intersectoral cooperation; that is, the coordinated work of Cuban government agencies, schools, media, and community. HIV education is thus not treated as an isolated program, but is supported by sex education in schools, television programs, and broader "sexual diversity" campaigns.

In spite of the serious effects of the US economic blockade, which limits access to foreign medicine and impedes scientific and professional exchange, Cuba's HIV / AIDS program has drawn on its intersectoral cooperation to help link community education, epidemiological surveillance, targeted testing, and thorough contact tracing. These elements are in turn backed up by a free public health system and a strong commitment to social solidarity. Cuba's experience deserves serious study by those concerned with effective and inclusive approaches to HIV / AIDS.

\section{SINOPSIS}

\section{La infección por el VIH/sida en Cuba: lecciones y retos}

Cuba presenta la tasa más baja de infección por el VIH en el Caribe. Este análisis toma en cuenta diferentes puntos de vista acerca de cómo Cuba alcanzó ese estatus y busca identificar los elementos clave de su éxito relativo. Contrario a lo expresado por una buena parte de la literatura extranjera, el aislamiento de los pacientes desempeñó un papel menor. Desde la perspectiva de los cubanos, los elementos de mayor peso fueron: la cooperación intersectorial, la vigilancia epidemiológica, la educación, la búsqueda dirigida y el tamizaje de los contactos, la cobertura gratuita de la salud pública y la solidaridad social. Los enfoques desarrollados más recientemente han sido la promoción de salud, la inclusión sexual, el programa llamado "hospital de dia", la educación continua de los pacientes, un mayor papel de los pares educadores y la cobertura de $100 \%$ de los seropositivos con el tratamiento antirretroviral.

Palabras clave: VIH, síndrome de inmunodeficiencia adquirida, promoción de la salud, Cuba.

\section{REFERENCES}

1. United Nations Program on HIV/AIDS, World Health Organization. AIDS epidemic update. Geneva:UNDP/WHO; December 2006. Available from: http:// data.unaids.org/pub/EpiReport/ 2006/2006_EpiUpdate_en.pdf.

2. Caribbean Epidemiology Center. The Caribbean HIV/AIDS epidemic: epidemiological status-success stories. 2003; 23(Oct):1. Available from: www. carec.org/documents/csr_supplement. pdf. Accessed on 23 December 2006.

3. United Nations Program on HIV/AIDS, World Health Organization. Adult (1549) HIV prevalence percent by country, 1990-2007. In: 2008 report on the global AIDS epidemic. Geneva: UNDP/WHO; July 2008.

4. de Arazoza H, Lounes R, Perez P, Hoang T. What percentage of the Cuban HIV-AIDS epidemic is known? Rev Cubana Med Trop. 2003;55(1). Available from: www.scielo.sld.cu/scielo.php? pid $=$ S0375-07602003000100005 \&script=sci_arttext. Accessed on 6 June 2006.

5. Pérez P, Pérez D, Gonzalez I, Diaz Jidy M, Orta M, Aragonés C, et al. Approaches to the management of HIV/ AIDS in Cuba. Case study: perspectives and practice in antiretroviral treatment.
Geneva: World Health Organization; 2004.

6. Vice-Ministerio de Higiene Epidemiologica (MINSAP). VIH/SIDA: datos fecha de cierre 22 noviembre 2005. Havana: Centro Nacional de Prevencion de las ITS/VIH/SIDA; 2005.

7. Vice-Ministerio de Higiene Epidemiologica (MINSAP). VIH/SIDA: datos fecha de cierre 28 agosto de 2007. Havana: Centro Nacional de Prevencion de las ITS/VIH/SIDA; 2007.

8. Infomed Red Telemática de Salud. ITS/ VIH/SIDA: epidemiología y estadística. Available from: www.sld.cu/servicios/ sida $/$ temas.php?idv=2240. Accessed on 12 December 2008.

9. United Nations General Assembly. General Assembly overwhelmingly supports end to United States embargo on Cuba. 8 November 2008. Available from: http:// www.un.org/News/Press/docs/2006/ ga10529.doc.htm. Accessed 15 January 2009.

10. Prensa Latina. Estados Unidos pretende silenciar logros de Cuba en lucha VIH/ SIDA. 4 June 2006. Available from: www.rebelion.org/noticia.php?id=324 99. Accessed on 10 June 2006.

11. Office of Foreign Assets Control. Cuba Sanctions. Available from: www.treas. gov/offices/enforcement/ofac/pro grams/cuba/cuba.shtml. Accessed on 3 March 2008.

12. Zonana V. Cuba's AIDS quarantine centre called "frightening." Los Angeles Times. 4 November 1988: Pp.1.

13. Bayer R, Healton C. Controlling AIDS in Cuba. The logic of quarantine. N Eng J Med. 1989;321(12):829-30.

14. Pérez-Stable E. Cuba's response to the HIV epidemic. Am J Public Health. 1991;81:563-7.

15. Bauza V, Collie T. HIV positive Cubans get care but live in quarantine. South Florida Sun-Sentinel. 7 July 2001; A4.

16. Hansen H, Groce N. Human Immunodeficiency Virus and quarantine in Cuba. JAMA. 2003;290:2875.

17. d'Adesky AC. Cuba fights AIDS its own way. American Foundation for AIDS Research. Available from: www.thebody. com/content/art32967.html.

18. Brotherton P. Macroeconomic change and the biopolitics of health in Cuba's special period. J Latin Am Anthro. 2005; 10(2):339-69.

19. Whiteford L, Branch LG. Primary health care in Cuba. Maryland: Rowman and Littlefield; 2008.

20. Fawthrop T. Cuba: is it a model in HIV-AIDS battle? Global Policy Forum; 
December 2003. Available from: www. globalpolicy.org/index.php?option= com_content\&amp;view=article\&amp; id $=44946 \&$ amp;catid $=211$. Accessed on 18 January 2006.

21. McKenna P. AIDS in Cuba. Toronto Star; 29 August 2004

22. United Nations Program on HIV/AIDS Cuba: country report 2005. Available from: www.unaids.org. Accessed 3 June 2006.

23. Galbán García E, de Quesada Ramírez E, Cádiz Lahens A. Programa de entrenamiento sobre el SIDA 3: Epidemiologia. Havana: Editorial Ciencias Medicas; 1989.

24. Centro de Hygenico y Epidemiologia. Personas infectadas en Municipio Plaza: 1986-2005. Vedado: Municipio Plaza; 20 November 2005.

25. Branson BM, Hunter Handsfield $\mathrm{H}$ Lampe MA, Janssen RS, Taylor AW, Lyss $\mathrm{SB}$, et al. Revised recommendations for HIV testing of adults, adolescents, and pregnant women in health-care settings. Centers for Disease Control and Prevention. MMWR. 22 September 2006;55 (RR14):1-17. Available from: http:// www.cdc.gov $/ \mathrm{mmwr} /$ preview $/ \mathrm{mmw}$ $\mathrm{rhtml} / \mathrm{rr} 5514 \mathrm{a} 1 . \mathrm{htm}$. Accessed 15 January 2009.

26. Álvarez González, A, Villalón Oramas M, Amargós González GM, Fonseca Robles N, Jiménez López L, Reyes Gómez W. Viviendo con VIH: manual para las personas que viven con VIH/ SIDA en Cuba, 2nd edition. Havana: Centro Nacional de Prevención de ITS/ VIH/SIDA. Havana; 2004.

27. Ochoa Soto R, Sánchez Fuentes J, Villalón Oramas M, Duque Santana I,
Hernández Fernández M, Pérez Pérez F. Manual para médicos de familia sobre ITS/VIH/SIDA. Havana: Ministerio de Salud Publica, Centro Nacional de Prevención de las ITS/VIH/SIDA; 2003.

28. Johnston DW. Cuba's quarantine of AIDS Victims: a violation of human rights. Boston College International Comparative Law Review. 1992;15:189.

29. Rodríguez Oliva LI. Modelos de Salud en Cuba. [Interview with Dr. Francisco Rojas Ochoa]. La Habana: julio-septiembre, 2006;(47):35-43.

30. Pérez J. SIDA: Confesiones a un Medico. La Habana: Centro Nacional de Prevención de las ITS/VIH/SIDA; 2006.

31. Rosabal Socarrás A. Derechos de las persons que viven con $\mathrm{VIH}$ en Cuba. Legalidad y perjuicios sociales. [T5-349 conference paper] 2003. Available from: www.foro2003.sld.cu. Accessed on 3 June 2006.

32. Holtz T. Summary of issue of HIV-AIDS in Cuba. APHA Cuba Tour, August 1997. Available from: www.cubasolidar ity.net/cubahol2.html. Accessed on 18 January 2006

33. Albear de la Torre O, Lugo Carro I. Conviviendo con $\mathrm{VIH}$ : manual dirigido a las familias de las personas que viven con VIH/SIDA en Cuba. Havana: Centro Nacional de Prevención de ITS/VIH/ SIDA; 2003.

34. Ochoa Soto R, Duque Santana I, Herández Fernández M, Chacon Asusta L, Ricardo Puig O, Pérez Pérez F, et al. Manual metologo: trabajo de prevención de la ITS/VIH/SIDA. Havana: Ministerio de Salud Publica. Centro Nacional de Prevención de las ITS/VIH/SIDA; 2004.
35. Ministerio de Salud Publica. Centro Nacional de Prevención de las ITS/HIV/ SIDA. Havana; 2005. [Brochure].

36. Castro M. Sexual diversity and inclusion in Cuba. Proceedings of the World Social Forum. Caracas, Venezuela; 28 January 2006.

37. Medical News Today. Cuba increasing HIV prevention efforts targeted at MSM, health official says. Available from: http://www.medicalnewstoday.com/. Accessed on 11 December 2008.

38. Hatch M. Gay Celebration in Cuba launches HIV prevention campaign. LGBT Cuba. Available from: http:// gaycuba.ca/together/. Accessed on 11 December 2008.

39. de Arazoza H, Joanes J, Lounes R, Legeai C, Clémençon S, Pérez J, Auvert B. The HIV/AIDS epidemic in Cuba: description and tentative explanation of its low HIV prevalence. BMC Infectious Diseases. Available from: http://www. biomedcentral.com/content/pdf/14712334-7-130.pdf. Accessed on 11 December 2008.

40. Gorry C. Cuba's HIV/AIDS strategy: an integrated, rights-based approach. Oxfam International. July 2008. Available from: http://www.medicc.org/ns/ assets/documents/Cuban $\% 20 \mathrm{HIV} \% 20$ Strategy.pdf. Accessed on 12 December 2008.

Manuscript received on 6 July 2008. Revised version accepted for publication on 11 February 2009. 